\title{
Targeting HMGB1 in the Treatment of Non-Small Cell Lung Adenocarcinoma
}

\author{
Brady Anderson ${ }^{1}$, Mary Vue ${ }^{2}$, Nya Gayluak ${ }^{2}$, Sarah Jane Brown ${ }^{3}$, Lynne T. Bemis ${ }^{4}$ (D) \\ and Glenn E. Simmons, Jr. ${ }^{4, *}$
}

1 Department of Biology, University of Minnesota Duluth, Duluth, MN 55812, USA; and05004@d.umn.edu

2 TRIO/McNair Scholar Program, College of St. Scholastica, Duluth, MN 55811, USA; mvue3@css.edu (M.V.); ygayluak@css.edu (N.G.)

3 Bio-Medical Library, University of Minnesota, Minneapolis, MN 55455, USA; sjbrown@umn.edu

4 Department of Biomedical Sciences, University of Minnesota School of Medicine, Duluth, MN 55812, USA; ltbemis@d.umn.edu

* Correspondence: gsimmons@d.umn.edu; Tel.: +1-218-726-8386

Citation: Anderson, B.; Vue, M.;

Gayluak, N.; Brown, S.J.; Bemis, L.T.; Simmons, G.E., Jr. Targeting HMGB1 in the Treatment of Non-Small Cell Lung Adenocarcinoma. Onco 2021, 1, 25-37. https://doi.org/10.3390/ onco1010004

Academic Editor:

Alessandro Morabito

Received: 23 May 2021

Accepted: 27 May 2021

Published: 4 June 2021

Publisher's Note: MDPI stays neutral with regard to jurisdictional claims in published maps and institutional affiliations.

Copyright: (c) 2021 by the authors. Licensee MDPI, Basel, Switzerland. This article is an open access article distributed under the terms and conditions of the Creative Commons Attribution (CC BY) license (https:// creativecommons.org/licenses/by/ $4.0 /)$.
Simple Summary: Lung cancer is the most commonly diagnosed cancer in the world, and with recent success of immunotherapy for cancer treatment, there is hope that a functional cure for lung cancer is within our grasp. However, many patients with lung cancer continue to have low response rates to immunotherapy such as immune checkpoint inhibitors. Innate immune proteins like High Mobility Group Box 1 (HMGB1) may be key to improving the effect of immune-based cancer treatment for patients that currently do not respond to therapy. This review outlines ways to target HMGB1 in order to alter the immune response across several in vivo and in vitro models.

Abstract: Evidence of immunogenic cell death as a predictor of response to cancer therapy has increased interest in the high molecular group box 1 protein (HMGB1). HMGB1 is a nuclear protein associated with chromatin organization and DNA damage repair. HMGB1 is also a damage-associated molecular pattern (DAMP) protein and promotes proinflammatory signaling in a paracrine and autocrine manner. Extracellular HMGB1 can promote activation of NF-kB and is associated with several chronic inflammatory and autoimmune diseases, including sepsis, rheumatoid arthritis, atherosclerosis, chronic kidney disease, systemic lupus erythematosus (SLE), as well as cancer. In this review, we describe studies that demonstrate the use of deacetylase inhibitors and HMGB1 inhibitors to alter the expression and localization of HMGB1 in cancer cells, with a focus on lung cancer. The drugs described herein are well established and frequently used in human and small mammal studies. The main objective of this review is to summarize the potential benefit of targeting posttranslational modification of HMGB1 to decrease inflammatory signaling in the tumor microenvironment, and perhaps lead to improved response to current immunotherapeutic approaches.

Keywords: cancer; immunotherapy; HMGB1; lung cancer; inflammation

\section{Introduction}

Lung cancer is the most common form of malignancy worldwide and is the leading cause of cancer-related deaths in both men and women. Like many cancers, lung cancer is particularly lethal as a result of its ability to effectively camouflage itself from the immune system, leading to late diagnosis and poor response to treatment [1,2]. This allows the uncontrolled growth of cancer cells and the establishment of an immunosuppressed microenvironment. The uncontrolled growth and local immunosuppression are associated with increases in metastatic growth and the development of tumors distal from the primary site [3]. Current treatment methods are heavily reliant on cytotoxic chemotherapies that target the rapidly growing cells that have dysfunctional DNA repair mechanisms. Molecular targeted therapy is a promising new therapeutic technique involving the interference of 
integral molecules in cancer growth and metastasis. These therapies often involve very little threat to the host in comparison to more traditional treatment methods and have demonstrated remarkable clinical success in the treatment of many cancer types including breast, leukemia, colorectal, lung, and ovarian cancers [4]. Novel targeted therapeutics with less toxicity have the potential to increase overall survival and radically change the quality-of-life of patients. The more recent advances in immunotherapies such as tumor cell-based vaccines, chimeric antigen $\mathrm{T}$ cells, and immune checkpoint inhibitors have increased the hope that less toxic therapies will become the norm [5]. In lung cancer for instance, the use of immune checkpoint inhibitors increases the survival rate of previously treated cancer patients from 5 to $16 \%$ [6]. However, there are many patients who do not benefit from these approaches at present, either due to cost, low expression of checkpoint molecules, or poor response to treatment. Therefore, improving our understanding of the immune response within the tumor microenvironment is likely to allow more patients to benefit from this new technology and perhaps improve the prognosis of patients that, despite our best efforts, could not be successfully treated in the past.

Within the tumor microenvironment, innate immune proteins reside that are capable of skewing the adaptive immune response in favor of either proinflammatory or antiinflammatory responses [7]. The elimination of neoplasms typically occurs following recruitment of cytotoxic immune cells elicited by pro-inflammatory cytokines like IL-1, IL6 , and TNF alpha [8-10]. However, the immune response is not a simple on/off mechanism especially in the context of cancer. Some innate immune molecules known as damage associated molecular pattern (DAMPs) initiate pro-inflammatory signaling, which recruit tumor infiltrating immune cells [11]. However this does not always result in the clearance of harmful cells or pathogens. In some instances, the immune response is suppressed by the expression of specific DAMPs [12]. One DAMP, high mobility group box 1 protein (HMGB1), has been shown to have both an activating and suppressive effect on the immune response [13-15]

HMGB1 is a non-histone chromatin packing protein that resides within the nucleus $[16,17]$. Under stress, HMGB1 dissociates from chromatin and relocates to the extracellular space $[18,19]$. Outside of the cell, HMGB1 is able to act as a ligand for a variety of receptors and stimulates recruitment of lymphocytes [13,20-22]. Understanding how HMGB1 expression regulates immunomodulation is an active area of research. Consequently, HMGB1 has been shown to be a major contributor to many inflammatory diseases [23-25], and its release can be altered by administering natural compounds and inhibition of deacetylases [26-29]. Increasing evidence suggests that HMGB1 has influence on the immune state within tumors $[14,15,30]$, which makes controlling HMGB1 localization in cancer cells a potential immunomodulatory target that could be used to induce anti-tumor cytotoxic lymphocyte activity. Herein, we systematically reviewed the literature for studies that utilize deacetylase and HMGB1 inhibitors to target HMGB1 in lung cancer and other select models of cancer and lung disease.

\section{Materials and Methods}

A medical librarian created the literature search strategy after meeting with a member of the research team to clarify goals and further define selection criteria. The search strategy was built in Ovid MEDLINE using Medical subject headings and keywords to describe the following concepts: HMGB1 inhibitors or HDAC inhibitors and cancers. The search was then translated to three other databases: EMBASE, Cochrane Library, and Scopus. Databases were chosen to be inclusive of international medical literature. Searches were run without limits from database inception through 29 April 2020. After deduplication, 490 titles and abstracts were uploaded to Rayyan [31] for independent review by two researchers. Following the title and abstract review, PDFs of 69 selected studies were uploaded for full-text screening and independently reviewed by two researchers (Figure 1). 


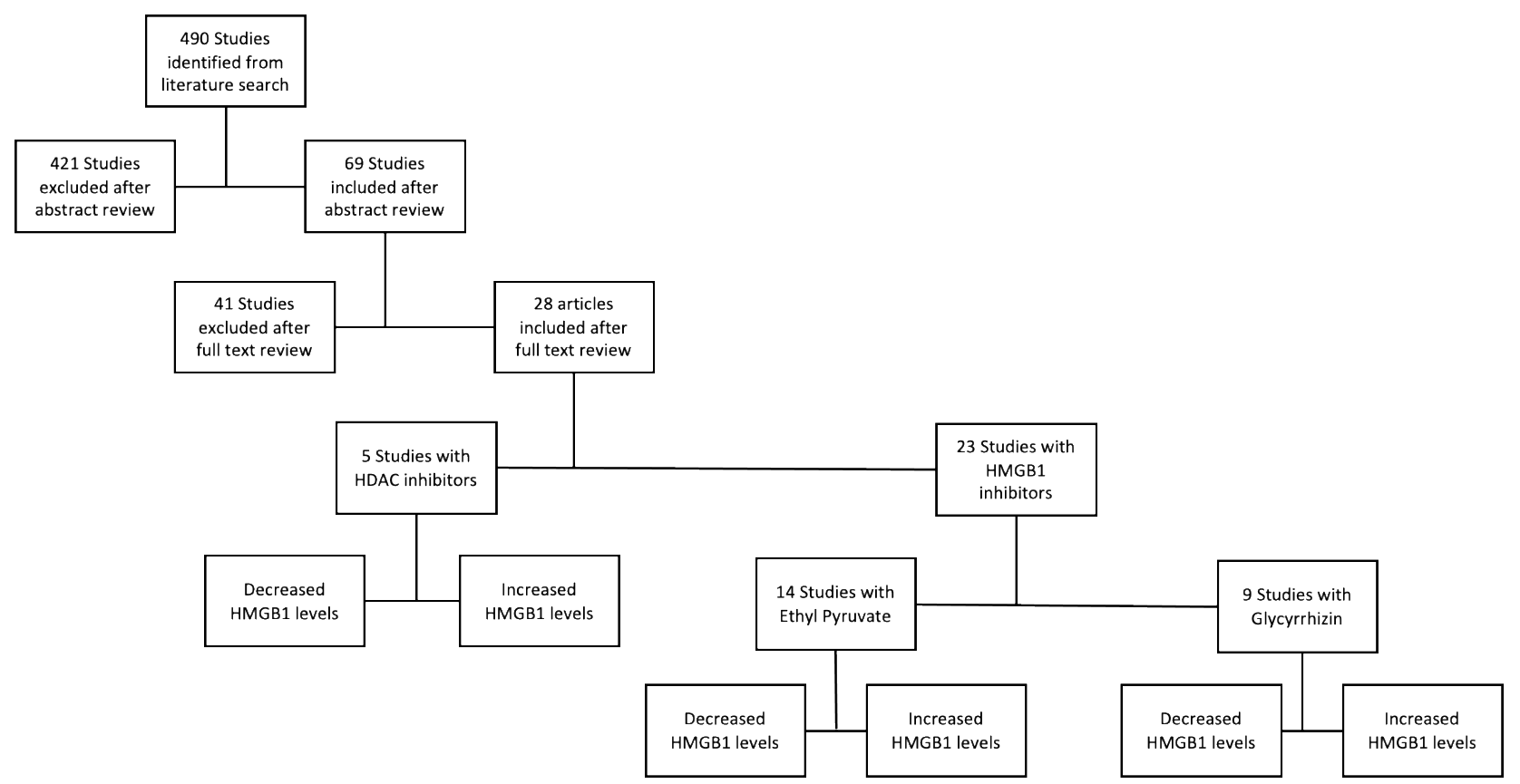

Figure 1. Schematic of data extraction from research studies included.

Studies were included if they met the following criteria: (1) The model systems described human patients with lung cancer, human cancer cell lines, or animal models of lung cancer or lung disease/injury; (2) Drugs were either HDAC inhibitors or HMGB1 inhibitors (glycyrrhizin or ethyl pyruvate); (3) Study was published in a full-text article. Studies were excluded if (1) they described animal models of cancers or diseases in organs other than the lung; (2) they were only reported in an abstract, poster, or conference presentation, etc. Twenty-nine studies met the criteria and were included in our analysis. Data was extracted from each study independently by two authors using a custom data extraction form that collected data on the following outcomes: HMGB1 gene and protein expression, extracellular HMGB1 protein level, five-year overall survival, and change in tumor size. Using the extracted data, summary statistical tables and figures were created using major themes of the model, drug used, HMGB1's cellular retention, HMGB1's release, tumor size, and survival (Table 1). This review is based on these major themes. 
Table 1. Targeting of HMGB1 in lung cancer and other disease models.

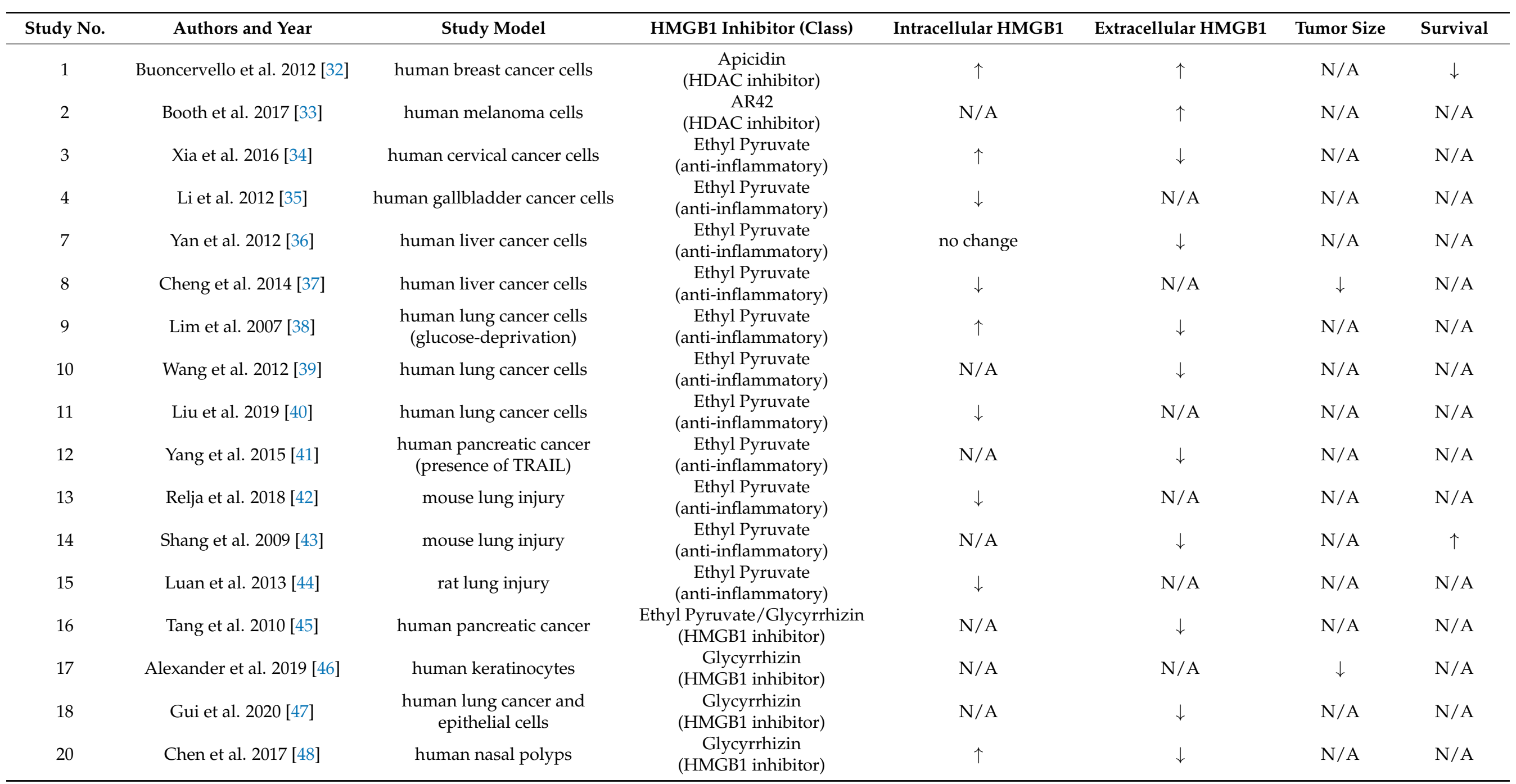


Table 1. Cont

\begin{tabular}{|c|c|c|c|c|c|c|c|}
\hline Study No. & Authors and Year & Study Model & HMGB1 Inhibitor (Class) & Intracellular HMGB1 & Extracellular HMGB1 & Tumor Size & Survival \\
\hline 21 & Gnanasekar et al. 2011 [49] & $\begin{array}{l}\text { human prostate cancer cells } \\
\text { (gene expression only) }\end{array}$ & $\begin{array}{c}\text { Glycyrrhizin } \\
\text { Ethyl Pyruvate } \\
\text { (HMGB1 inhibitor) }\end{array}$ & $\downarrow$ & $\mathrm{N} / \mathrm{A}$ & $\mathrm{N} / \mathrm{A}$ & $\mathrm{N} / \mathrm{A}$ \\
\hline 23 & Wu et al. 2018 [51] & $\begin{array}{l}\text { human non-small cell lung } \\
\text { carcinoma cells }\end{array}$ & $\begin{array}{c}\text { Glycyrrhizin } \\
\text { (HMGB1 inhibitor) }\end{array}$ & $\downarrow$ & $\mathrm{N} / \mathrm{A}$ & $\downarrow$ & $\mathrm{N} / \mathrm{A}$ \\
\hline 24 & Qiu et al. 2019 [52] & mouse lung cancer cells & $\begin{array}{c}\text { Glycyrrhizin } \\
\text { (HMGB1 inhibitor) }\end{array}$ & $\mathrm{N} / \mathrm{A}$ & $\downarrow$ & $\mathrm{N} / \mathrm{A}$ & $\mathrm{N} / \mathrm{A}$ \\
\hline 25 & Yao et al. 2019 [53] & mouse lung injury & $\begin{array}{c}\text { Glycyrrhizin } \\
\text { (HMGB1 inhibitor) }\end{array}$ & $\mathrm{N} / \mathrm{A}$ & $\downarrow$ & $\mathrm{N} / \mathrm{A}$ & $\uparrow$ \\
\hline 26 & Booth et al. 2017 [33] & human lung & $\begin{array}{l}\text { Valproic acid } \\
\text { (HDAC inhibitor) }\end{array}$ & $\mathrm{N} / \mathrm{A}$ & $\uparrow$ & $\mathrm{N} / \mathrm{A}$ & $\mathrm{N} / \mathrm{A}$ \\
\hline 27 & Li et al. 2018 [54] & mouse lung injury & $\begin{array}{l}\text { Sodium butyrate } \\
\text { (HDAC inhibitor) }\end{array}$ & $\mathrm{N} / \mathrm{A}$ & $\downarrow$ & $\mathrm{N} / \mathrm{A}$ & $\mathrm{N} / \mathrm{A}$ \\
\hline 28 & Luo et al. 2013 [55] & human colon cancer & $\begin{array}{c}\text { Trichostatin A } \\
\text { (HDAC inhibitor) }\end{array}$ & $\mathrm{N} / \mathrm{A}$ & $\downarrow$ & $\downarrow$ & $\mathrm{N} / \mathrm{A}$ \\
\hline
\end{tabular}




\section{Results}

\subsection{HMGB1, the Proinflammatory Molecule}

HMGB1 is a nuclear protein that has a structural role in DNA damage repair [56-59]. It is anchored in the nucleus by interactions between its nuclear localization sequence (NLS) and nuclear transport proteins. Although it normally participates in DNA repair, HMGB1 has also been demonstrated to inhibit DNA damage repair when exposed to platinum-based cancer therapeutics $[56,60,61]$. HMGB1's nuclear function and interactions with other nuclear proteins is a potential area for future research [62-64]; however, this review is largely focused on HMGB1's role outside of the cell.

While nuclear HMGB1 helps regulate gene expression and DNA repair, extracellular HMGB1 has a significant role as a proinflammatory molecule. HMGB1 belongs to a class of proteins called alarmins, also known as damage-associated molecular pattern (DAMP) molecules [65]. These proteins are active in a wide variety of pathologies that relate to cellular damage or distress. During infection or cellular damage, HMGB1 is transported out to the cytoplasm and into the extracellular space [17]. Several studies have described how exposure of immune cells to bacterial endotoxin leads to release of HMGB1 [66-68], while a more recent study demonstrated that HMGB1 secretion is mediated through processes tied to a type of programmed cell death known as pyroptosis that is characterized by activation of the NLRP3 inflammasome [69]. Therefore, HMGB1 release from cells is tied to multiple stimuli that illicit inflammatory processes.

HMGB1 localization is regulated through a series of post-translational modifications. Additions such as methylation, phosphorylation, and acetylation can alter how HMGB1 interacts with chaperone proteins and DNA, which in turn alters its localization and function [70,71]. For instance, phosphorylation of specific residues in HMGB1 alters its nuclear localization [72]. Similar observations have been made regarding acetylation. Acetylation is the most well-characterized modification of HMGB1. Acetylation of several lysine residues within both HMGB1 nuclear localization sequences (NLS1 and NLS2) regulates the secretion of HMGB1 to the extracellular space [72,73]. There are 17 lysine residues that can be modified by acetylation. It has been shown that residues 17,28 , and 29 in the NLS1, and 179, 181, 183, and 184 in NLS2 are the most frequently critical to acetylation-dependent nuclear export (Figure 2). Interestingly, secretion of HMGB1 does not require conventional secretory mechanisms involving the endoplasmic reticulum like other secreted cytolsolic molecules [74]. Instead, HMGB1 has been shown to be released via gasdermin-independent membrane pores generated during inflammasome activation [69]. Together, this supports the idea that NLS domains within HMGB1 may be potential candidates for targeted therapies for inflammatory disorders [68].

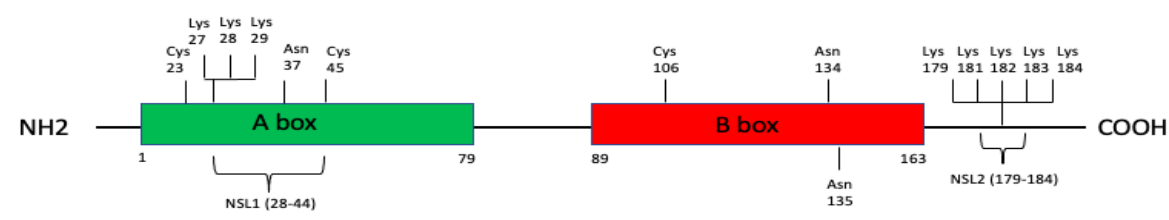

Figure 2. Sites of posttranslational modifications in the amino acid sequence of HMGB1.

Methylation has also been demonstrated to alter HMGB1 function. Unlike phosphorylation and acetylation, methylation affects the ability of HMGB1 to interact with DNA, while affecting its localization [70]. In addition to the aforementioned, there are two additional modifications of potential interest for future studies, namely glycosylation, and ADP-ribosylation. Glycosylation of HMGB1 appears to be limited to N-glycosylation of asparagine residues [74]. Glycosylation of HMGB1 influences interactions with an important binding partner chromosomal maintenance 1 (CRM1) in the nucleus. CRM1, also known as exportin 1, is a nuclear export protein. Glycosyl-moieties on HMGB1 promotes interactions between the two proteins and promotes movement of HMGB1 out of the nucleus [74]. In this way, it is possible that glycosylation may be equally as important 
as acetylation to HMGB1 movement. The last protein modification to discuss here is ADP-ribosylation (PARylation). PARylation is a more recently identified modification of HMGB1, but it has also been demonstrated to be important to the process of nuclear export and the release of HMGB1 during necrotic cell death [66,70]. PARylated HMGB1 amplifies the pro-inflammatory capacity of HMGB1. It does this in part by facilitating the interaction of HMGB1 with RAGE receptors, which signal to activate the transcriptional activity of NF-kB $[39,75]$.

The extracellular function of HMGB1 is dictated by its redox state. Key cysteine residues in the HMGB1 protein are responsible for its redox sensitivity. Three residues (cysteine 23, 45, and 106) are all fully reduced in the nucleus [76]. Movement of HMGB1 out of the nucleus leads to the subsequent oxidation of these cysteines, two of these residues (23 and 45) form disulfide bonds [76,77]. Fully oxidized HMGB1 has less proinflammatory capacity than its reduced form. This is likely because reduced HMGB1 is not actively released from cells, unless they are damaged or dying, as opposed to the active secretion of the oxidized form [76]. Partially oxidized HMGB1 has more inflammatory potential and interacts with a few different extracellular receptors, taking part in various cellular processes. Based on these interactions, extracellular HMGB1 serves as a ligand for cell surface receptors and promotes the expression of cytokines. These cytokines are hallmarks of inflammation and are present at elevated levels in human diseases like obesity and cancer, further illustrating the central role HMGB1 has as a critical mediator of systemic inflammation.

\subsection{HMGB1 as a Therapeutic Target}

Inflammation is a major component of the innate immune response designed to prime the body to fight potential infection or eliminate damaged or aged tissues. HMGB1 is a part of that response and is actively secreted by activated macrophages and other cells $[17,68]$. HMGB1 can be released by activated inflammatory cells and may even accumulate during infection or injury. Once released, extracellular HMGB1 is a ligand for multiple cell surface receptors (RAGE, TLR2, and TLR4) [25,78-80]. Interactions with RAGE, TLR2, or TLR4 by HMGB1 leads to the phosphorylation and activation of kinases interleukin-1 receptor associated kinases (IRAKs, IRAK1, 2, and 4) and mitogen-activated protein kinases (MAPKs, such as p38, JNK, and ERK) that activate the downstream transcription factors AP-1 and $\mathrm{NF}-\mathrm{kB}$, leading to proliferative and inflammatory responses [53,81]. This signaling cascade leads to additional release of HMGB1 and ultimately the increased expression of NF-kB target genes such as tumor necrosis factor-alpha (TNF- $\alpha$ ), interleukin-6 (IL-6), interleukin-8 (IL-8), interleukin-1 $\beta$ (IL-1 $\beta$ ), and interferon gamma (IFN- $\gamma$ ) [42]. TNF- $\alpha$, IL-6, and IL8 , promote tumor growth through TLR-mediated signaling pathways, thus promoting ERK1/2, NF-KB, and STAT3 activation [40].

The role of inflammation in initiating malignant disease is well established. As such, we thought it was critical to include an example of non-malignant inflammatory lung dysfunction to highlight the roles of HMGB1 in disease. Acute lung injury (ALI) is a type of respiratory failure marked by the rapid and widespread onset of inflammation throughout the lungs. Disease progression in ALI is characterized by cytokine mediated inflammation through increasing HMGB1 production as well as proinflammatory cytokines like TNF- $\alpha$, IL-6, and IL-8 through NF- $\mathrm{KB}$ activation $[43,44]$. In a mouse model of lung injury, circulating HMGB1 and the elevated NF- $\mathrm{KB}$ activity was associated with disease severity, suggesting that HMGB1 could be used to monitor disease progression [42]. The systemic inflammatory response observed in ALI is similar to what is seen in the tumor microenvironment. Across many disease models, the importance of understanding the role of extracellular HMGB1 in disease outcomes has become increasingly evident. Due to the positive feedback that inflammation has on HMGB1 secretion, HMGB1 tends to amplify inflammatory responses in various pathological conditions [44]. While studies have shown that inflammatory cytokines mediate acute lung injury (ALI), increased serum levels of HMGB1 are associated with worse prognosis [43]. Often increased levels of HMGB1 are 
correlated with the RAGE receptor and its role in promoting the phenotype associated with many inflammatory diseases and various tumors.

As mentioned earlier, HMGB1 signaling via RAGE and TLRs leads to activation of NF$\kappa B$; however, NF- $\kappa B$ is not only a mediator of inflammation, but also has an important factor in tumor survival. NF- $\mathrm{KB}$ activity can antagonize programmed cell death and promote mitogenic signaling, which both are advantageous to growing cancer cells [40]. This was evident in studies that highlighted the relationship between HMGB1 and cancer metastasis in xenograft models for lung cancer [50]. HMGB1 released from apoptotic cancer cells, following administration of chemotherapeutic drugs, was complexed with nucleosome DNA. These HMGB1-DNA complexes were suitable ligands for another member of the toll-like receptor family, TLR9 [19,35]. HMGB1 binding TLR9 led to increased metastasis in animal models of human lung cancer. This would suggest that treating patients with chemotherapeutic drugs could lead to subsequent metastatic cancer events. This idea is supported by evidence that patients undergoing chemotherapy treatments have significantly elevated levels of HMGB1-nucleosomes in their blood. Taken together, these results strongly support the exploration of methods to inhibit extracellular HMGB1 activity in patients to improve outcomes.

\subsection{Blocking the Release of HMGB1 Using Anti-Inflammatory Therapeutics}

Therapeutics that have anti-inflammatory properties have been shown to inhibit the release of HMGB1. Among those are ethyl pyruvate and glycyrrhizin. Release of HMGB1 is blocked when ethyl pyruvate suppresses HMGB1/RAGE axis in liver, pancreatic and non-small cell lung cancer leading to decreased cell growth [37-41]. In addition to ethyl pyruvate suppressing HMGB1 protein release, it decreases RAGE receptor expression, which leads to a decrease in HMGB1-mediated cell proliferation [42]. HMGB1 release is also reduced with ethyl pyruvate treatment of cervical cancer cells, resulting in increased intracellular HMGB1 and decreased cell proliferation causing increased levels of HMGB1 inside the cell [34].

Similarly, glycyrrhizin, a naturally occurring inhibitor of HMGB1 found in licorice, acts as an anti-inflammatory therapeutic and blocks the release of HMGB1. Glycyrrhizin has been shown to inhibit growth in lung cancer cells [48,51]. It directly interacts with the two shallow concave surfaces formed by the arms of the HMGB1 box regions [47]. Glycyrrhizin inhibits HMGB1 accumulation in the extracellular space, and prevents its interaction with proinflammatory receptors like TLR4, TLR2, and RAGE receptors [82-85]. Diseases where inflammation is a major factor in pathogenesis such as oncogenic transformation, bacterial infection, or diet-induced symbiosis are also sensitive to treatment with glycyrrhizin $[46,49,52,53]$. Conversely, the anti-inflammatory transforming growth factor (TGF-B1) pathway has been implicated in the cellular retention of HMGB1. Epithelialmesenchymal transition (EMT) promotes cell migration, invasion, and ultimately metastasis. TGF-B1 drives EMT through increased vimentin expression, decreased E-cadherin expression, which is associated with subsequent HMGB1 release [47]. Treatment of cells undergoing EMT with glycyrrhizin increased HMGB1 retention and restored E-cadherin levels. In nasal epithelial cells, glycyrrhizin cooperated with sirtuin 6 (SIRT6), a protein deacetylase, and inhibited translocation of HMGB1 from the nucleus, preventing extracellular release [48].

Therefore, several lines of evidence illustrate that cellular retention of HMGB1 increases in the cells exposed to glycyrrhizin or ethyl pyruvate.

\subsection{HDAC Inhibitors Increasing HMGB1 Release}

As previously mentioned, deacetylases (i.e., SIRT6) cooperate to regulate aspects of HMGB1 biology, making modulating their function an attractive method to control HMGB1. Histone deacetylases (HDAC) inhibitors are a class of compounds that increase the acetylation of lysine residues on histone proteins by inhibiting the activity of HDAC enzymes. In cancer, HDAC inhibitors inhibit the proliferation of tumor cells in culture and in-vivo by 
inducing apoptosis and cell cycle arrest [85]. Cellular localization of HMGB1 is dictated by the presence or absence of acetyl groups on the protein. HMGB1 release occurs in cells that are undergoing necrosis or inflammasome activation [86]. Regulation of deacetylase enzymes is a rational approach to preventing active release of HMGB1 [33]. HMGB1 release occurs in cells that are undergoing necrosis or inflammasome activation [87]. Regulation of deacetylase enzymes is a rational approach to preventing active release of HMGB1.

HDAC inhibitors, including AR-42, trichostatin A, sodium butyrate, and sodium valproate (valproic acid), promote release of HMGB1 $[54,55,88]$. Melanoma cells containing B-raf mutations have been shown to have sensitivity to HDAC inhibition. The sensitivity may be linked to the decreased levels of HMGB1 following HDAC inhibition. In many tumors, pemetrexed and sildenafil promoted the extracellular release of HMGB1 [88]. In fact, pemetrexed and sildenafil-mediated lethality was enhanced by the addition of HDAC inhibitors AR-42 and valproic acid in lung cancer models. In metastatic human breast cancer cells, increased HMGB1 cytoplasmic accumulation and release also occurred following treatment with HDAC inhibitors [32]. Together, these data demonstrate that the relationship between HMGB1 and acetylation is key to important aspects of tumor development. Therefore, this is additional evidence indicating the need to investigate ways to regulate HMGB1 in vivo to improve response to therapy and increase overall survival.

\section{Discussion}

HMGB1 is a multifaceted protein with roles in genomic stability and immune response. As research on HMGB1 has expanded, it has become clear that HMGB1 is involved with several key pathways necessary for normal cell function. Yet in tumorigenesis, the role of HMGB1 appears to be important, but still incompletely understood. Currently, the research is divided on whether HMGB1 is a benefit or detriment to the development of malignant neoplasia. This is due, in part to the role of HMGB1 in DNA damage repair in the nucleus, inflammatory signaling in the extracellular space, and immunosuppression in coordination with regulatory $\mathrm{T}$ cells [36]. As immunotherapy for cancer becomes more widely available, it is becoming even more critical to understand the mechanisms that tumors employ to evade immunosurveillance and prevent natural defenses from eliminating growing malignancies. For instance, HMGB1 promotes an immunosuppressive environment by stimulating the expression of immune checkpoint molecule PD-L1 in melanoma cells [89]. Conversely, and most relevant to the intent of this review, combinations of small molecules inhibitors of HMGB1 along with anti-PD-L1 therapy improved the overall efficacy of the cancer immunotherapy [90]. These data suggest that HMGB1 is potentially a synergistic molecular target for immunotherapy in solid tumors. However, there are currently gaps in the literature that need to be filled to demonstrate the proof of concept for therapeutic use of anti-HMGB1 drugs as therapeutically valuable. Robust pre-clinical studies are needed to validate this strategy in human patients. In support of such an approach, extracellular HMGB1 is readily detectable by immunological assays, which could allow clinicians to determine the utility of inhibitors using minimally invasive procedures.

The studies cited in this review utilize several compounds that have an inhibitory effect on HMGB1. Based on our survey of the available literature involving HMGB1-targeting in lung cancer using in vivo and in vitro models, there was limited research identified in this area, which signifies the gap in knowledge and an opportunity to observe the role of HMGB1 inhibition and its role in cancer in clinical and pre-clinical models. The inhibitors included in this review (glycyrrhizin, valproic acid, ethyl pyruvate) are all compounds that are known to be reasonably safe in humans and have at least some evidence of providing benefit to patients with a variety of different maladies. Our hope is that based on this summary of the available research, it has become clearer that incorporating HMGB1 into strategies for treating solid tumors is an underutilized approach that could have significant benefit for disease outcomes. 
Author Contributions: Conceptualization, G.E.S.J.; methodology, G.E.S.J. and S.J.B.; formal analysis, B.A., M.V., N.G., G.E.S.J.; writing-original draft preparation, B.A., M.V., N.G., S.J.B., L.T.B. and G.E.S.J.; writing-review and editing, B.A., M.V., N.G., S.J.B., L.T.B. and G.E.S.J. All authors have read and agreed to the published version of the manuscript.

Funding: This research was funded by the National Institutes of Health's National Center for Advancing Translational Sciences (Grant No. UL1TR002494).

Institutional Review Board Statement: Not applicable for studies not involving humans or animals. Informed Consent Statement: Not applicable for studies not involving humans or animals.

Data Availability Statement: No new data were created or analyzed in this study. Data sharing is not applicable to this article.

Conflicts of Interest: The authors declare no conflict of interest. The funders had no role in the design of the study; in the collection, analyses, or interpretation of data; in the writing of the manuscript, or in the decision to publish the results.

\section{References}

1. Abdel-Rahman, O.; Cheung, W.Y. Subsequent thoracic cancers among patients diagnosed with lung cancer: A SEER database analysis. Curr. Med. Res. Opin. 2017, 33, 2009-2017. [CrossRef] [PubMed]

2. Khong, H.T.; Restifo, N.P. Natural selection of tumor variants in the generation of 'tumor escape' phenotypes. Nat. Immunol. 2002, 3, 999-1005. [CrossRef] [PubMed]

3. Perea, F.; Sánchez-Palencia, A.; Gómez-Morales, M.; Bernal, M.; Concha, Á.; García, M.M.; González-Ramírez, A.R.; Kerick, M.; Martin, J.; Garrido, F.; et al. HLA class I loss and PD-L1 expression in lung cancer: Impact on T-cell infiltration and immune escape. Oncotarget 2017, 9, 4120-4133. [CrossRef] [PubMed]

4. Lee, Y.T.; Tan, Y.J.; Oon, C.E. Molecular targeted therapy: Treating cancer with specificity. Eur. J. Pharmacol. 2018, 834, 188-196. [CrossRef]

5. Zappa, C.; Mousa, S.A. Non-small cell lung cancer: Current treatment and future advances. Transl. Lung Cancer Res. 2016, 5, 288-300. [CrossRef] [PubMed]

6. Garon, E.B.; Hellmann, M.D.; Rizvi, N.A.; Carcereny, E.; Leighl, N.B.; Ahn, M.-J.; Eder, J.P.; Balmanoukian, A.S.; Aggarwal, C.; Horn, L.; et al. Five-Year Overall Survival for Patients with Advanced Non-Small-Cell Lung Cancer Treated with Pembrolizumab: Results from the Phase I KEYNOTE-001 Study. J. Clin. Oncol. 2019, 37, 2518-2527. [CrossRef]

7. Chiba, S.; Baghdadi, M.; Akiba, H.; Yoshiyama, H.; Kinoshita, I.; Dosaka-Akita, H.; Fujioka, Y.; Ohba, Y.; Gorman, J.V.; Colgan, J.D.; et al. Tumor-infiltrating DCs suppress nucleic acid-mediated innate immune responses through interactions between the receptor TIM-3 and the alarmin HMGB1. Nat. Immunol. 2012, 13, 832-842. [CrossRef]

8. Candido, J.; Hagemann, T. Cancer-Related Inflammation. J. Clin. Immunol. 2013, 33, 79-84. [CrossRef] [PubMed]

9. Erez, N.; Glanz, S.; Raz, Y.; Avivi, C.; Barshack, I. Cancer Associated Fibroblasts express pro-inflammatory factors in human breast and ovarian tumors. Biochem. Biophys. Res. Commun. 2013, 437, 397-402. [CrossRef]

10. Zhang, H.Y.; Zhang, Q.; Zhang, X.; Yu, C.; Huo, X.; Cheng, E.; Wang, D.H.; Spechler, S.J.; Souza, R.F. Cancer-related inflammation and Barrett's carcinogenesis: Interleukin-6 and STAT3 mediate apoptotic resistance in transformed Barrett's cells. Am. J. Physiol. Liver Physiol. 2011, 300, G454-G460. [CrossRef]

11. Cottone, L.; Capobianco, A.; Gualteroni, C.; Monno, A.; Raccagni, I.; Valtorta, S.; Canu, T.; Di Tomaso, T.; Lombardo, A.L.; Esposito, A.; et al. Leukocytes recruited by tumor-derived HMGB1 sustain peritoneal carcinomatosis. OncoImmunology 2016, 5, e1122860. [CrossRef]

12. Barua, S.; Fang, P.; Sharma, A.; Fujimoto, J.; Wistuba, I.; Rao, A.U.; Lin, S.H. Spatial interaction of tumor cells and regulatory T cells correlates with survival in non-small cell lung cancer. Lung Cancer 2018, 117, 73-79. [CrossRef] [PubMed]

13. Su, Z.; Sun, C.; Zhou, C.; Liu, Y.; Zhu, H.; Sandoghchian, S.; Zheng, D.; Peng, T.; Zhang, Y.; Jiao, Z.; et al. HMGB1 blockade attenuates experimental autoimmune myocarditis and suppresses Th17-cell expansion. Eur. J. Immunol. 2011, 41, $3586-3595$. [CrossRef] [PubMed]

14. Wild, C.A.; Bergmann, C.; Fritz, G.; Schuler, P.; Hoffmann, T.K.; Lotfi, R.; Westendorf, A.; Brandau, S.; Lang, S. HMGB1 conveys immunosuppressive characteristics on regulatory and conventional T cells. Int. Immunol. 2012, 24, 485-494. [CrossRef]

15. Li, J.; Sun, J.; Rong, R.; Li, L.; Shang, W.; Song, D.; Feng, G.; Luo, F. HMGB1 promotes myeloid-derived suppressor cells and renal cell carcinoma immune escape. Oncotarget 2017, 8, 63290-63298. [CrossRef]

16. Chikhirzhina, E.; Starkova, T.; Beljajev, A.; Polyanichko, A.; Tomilin, A. Functional Diversity of Non-Histone Chromosomal Protein HmgB1. Int. J. Mol. Sci. 2020, 21, 7948. [CrossRef]

17. Scaffidi, P.; Misteli, T.; Bianchi, M.E. Release of chromatin protein HMGB1 by necrotic cells triggers inflammation. Nat. Cell Biol. 2002, 418, 191-195. [CrossRef]

18. He, S.; Cheng, J.; Sun, L.; Wang, Y.; Wang, C.; Liu, X.; Zhang, Z.; Zhao, M.; Luo, Y.; Tian, L.; et al. HMGB1 released by irradiated tumor cells promotes living tumor cell proliferation via paracrine effect. Cell Death Dis. 2018, 9, 1-13. [CrossRef] [PubMed] 
19. Tsung, A.; Tohme, S.; Billiar, T.R. High-mobility group box-1 in sterile inflammation. J. Intern. Med. 2014, 276, 425-443. [CrossRef]

20. Li, J.; Wang, F.-P.; She, W.-M.; Yang, C.-Q.; Li, L.; Tu, C.-T.; Wang, J.-Y.; Jiang, W. Enhanced high-mobility group box 1 (HMGB1) modulates regulatory $\mathrm{T}$ cells (Treg)/ T helper 17 (Th17) balance via toll-like receptor (TLR)-4-interleukin (IL)-6 pathway in patients with chronic hepatitis B. J. Viral Hepat. 2013, 21, 129-140. [CrossRef]

21. Park, I.A.; Heo, S.-H.; Song, I.H.; Kim, Y.-A.; Park, H.S.; Bang, W.S.; Park, S.Y.; Jo, J.-H.; Lee, H.J.; Gong, G. Endoplasmic reticulum stress induces secretion of high-mobility group proteins and is associated with tumor-infiltrating lymphocytes in triple-negative breast cancer. Oncotarget 2016, 7, 59957-59964. [CrossRef]

22. Shi, Y.; Shotorbani, S.S.; Su, Z.; Liu, Y.; Tong, J.; Zheng, D.; Chen, J.; Liu, Y.; Xu, Y.; Jiao, Z.; et al. Enhanced HMGB1 Expression May Contribute to Th17 Cells Activation in Rheumatoid Arthritis. Clin. Dev. Immunol. 2011, 2012, 295081. [CrossRef]

23. De Souza, A.; Westra, J.; Limburg, P.; Bijl, M.; Kallenberg, C. HMGB1 in vascular diseases: Its role in vascular inflammation and atherosclerosis. Autoimmun. Rev. 2012, 11, 909-917. [CrossRef]

24. Li, W.; Sama, A.E.; Wang, H. Role of HMGB1 in cardiovascular diseases. Curr. Opin. Pharmacol. 2006, 6, 130-135. [CrossRef] [PubMed]

25. Nogueira-Machado, J.A.; Volpe, C.M.D.O.; Veloso, C.A.; Chaves, M.M. HMGB1, TLR and RAGE: A functional tripod that leads to diabetic inflammation. Expert Opin. Ther. Targets 2011, 15, 1023-1035. [CrossRef] [PubMed]

26. Gao, R.; Ma, Z.; Hu, Y.; Chen, J.; Shetty, S.; Fu, J. Sirt1 restrains lung inflammasome activation in a murine model of sepsis. Am. J. Physiol. Cell. Mol. Physiol. 2015, 308, L847-L853. [CrossRef]

27. Rabadi, M.M.; Xavier, S.; Vasko, R.; Kaur, K.; Goligorksy, M.S.; Ratliff, B.B. High-mobility group box 1 is a novel deacetylation target of Sirtuin1. Kidney Int. 2015, 87, 95-108. [CrossRef]

28. Schiraldi, M.; Raucci, A.; Muñoz, L.M.; Livoti, E.; Celona, B.; Venereau, E.; Apuzzo, T.; De Marchis, F.; Pedotti, M.; Bachi, A.; et al. HMGB1 promotes recruitment of inflammatory cells to damaged tissues by forming a complex with CXCL12 and signaling via CXCR4. J. Exp. Med. 2012, 209, 551-563. [CrossRef] [PubMed]

29. Wu, T.-Y.; Liu, L.; Zhang, W.; Zhang, Y.; Liu, Y.-Z.; Shen, X.-L.; Gong, H.; Yang, Y.-Y.; Bi, X.-Y.; Jiang, C.-L.; et al. High-mobility group box-1 was released actively and involved in LPS induced depressive-like behavior. J. Psychiatr. Res. 2015, 64, 99-106. [CrossRef]

30. Liu, Z.; Falo, L.D.; You, Z. Knockdown of HMGB1 in Tumor Cells Attenuates Their Ability to Induce Regulatory T Cells and Uncovers Naturally Acquired CD8 T Cell-Dependent Antitumor Immunity. J. Immunol. 2011, 187, 118-125. [CrossRef]

31. Ouzzani, M.; Hammady, H.; Fedorowicz, Z.; Elmagarmid, A. Rayyan-A web and mobile app for systematic reviews. Syst. Rev. 2016, 5, 1-10. [CrossRef]

32. Buoncervello, M.; Borghi, P.; Romagnoli, G.; Spadaro, F.; Belardelli, F.; Toschi, E.; Gabriele, L. Apicidin and Docetaxel Combination Treatment Drives CTCFL Expression and HMGB1 Release Acting as Potential Antitumor Immune Response Inducers in Metastatic Breast Cancer Cells. Neoplasia 2012, 14, 855-867, IN17-IN19. [CrossRef]

33. Booth, L.; Roberts, J.L.; Poklepovic, A.; Kirkwood, J.; Dent, P. HDAC inhibitors enhance the immunotherapy response of melanoma cells. Oncotarget 2017, 8, 83155-83170. [CrossRef] [PubMed]

34. Xia, J.; Yu, X.; Song, X.; Li, G.; Mao, X.; Zhang, Y. Inhibiting the cytoplasmic location of HMGB1 reverses cisplatin resistance in human cervical cancer cells. Mol. Med. Rep. 2016, 15, 488-494. [CrossRef] [PubMed]

35. Li, M.-L.; Wang, X.-F.; Tan, Z.-J.; Dong, P.; Gu, J.; Lu, J.-H.; Wu, X.-S.; Zhang, L.; Ding, Q.-C.; Wu, W.-G.; et al. Ethyl Pyruvate Administration Suppresses Growth and Invasion of Gallbladder Cancer Cells via Downregulation of Hmgb1-Rage Axis. Int. J. Immunopathol. Pharmacol. 2012, 25, 955-965. [CrossRef] [PubMed]

36. Yan, W.; Chang, Y.; Liang, X.; Cardinal, J.S.; Huang, H.; Thorne, S.H.; Monga, S.P.S.; Geller, D.A.; Lotze, M.T.; Tsung, A. Highmobility group box 1 activates caspase-1 and promotes hepatocellular carcinoma invasiveness and metastases. Hepatology 2012, 55, 1863-1875. [CrossRef]

37. Cheng, P.; Dai, W.; Wang, F.; Lu, J.; Shen, M.; Chen, K.; Li, J.; Zhang, Y.; Wang, C.; Yang, J.; et al. Ethyl pyruvate inhibits proliferation and induces apoptosis of hepatocellular carcinoma via regulation of the HMGB1-RAGE and AKT pathways. Biochem. Biophys. Res. Commun. 2014, 443, 1162-1168. [CrossRef]

38. Lim, S.-C.; Choi, J.E.; Kim, C.H.; Duong, H.-Q.; Jeong, G.-A.; Kang, H.S.; Han, S.I. Ethyl pyruvate induces necrosis-to-apoptosis switch and inhibits high mobility group box protein 1 release in A549 lung adenocarcinoma cells. Int. J. Mol. Med. 2007, 20, 187-192. [CrossRef]

39. Wang, C.; Fei, G.; Liu, Z.; Li, Q.; Xu, Z.; Ren, T. HMGB1 was a pivotal synergistic effector for CpG oligonucleotide to enhance the progression of human lung cancer cells. Cancer Biol. Ther. 2012, 13, 727-736. [CrossRef]

40. Liu, Q.; Huo, Y.; Zheng, H.; Zhao, J.; Jia, L.; Wang, P. Ethyl pyruvate suppresses the growth, invasion and migration and induces the apoptosis of non-small cell lung cancer cells via the HMGB1/RAGE axis and the NF-kappaB/STAT3 pathway. Oncol. Rep. 2019, 42, 817-825. [CrossRef]

41. Yang, M.; Liu, L.; Xie, M.; Sun, X.; Yu, Y.; Kang, R.; Yang, L.; Zhu, S.; Cao, L.; Tang, D. Poly-ADP-ribosylation of HMGB1 regulates TNFSF10/TRAIL resistance through autophagy. Autophagy 2015, 11, 214-224. [CrossRef]

42. Relja, B.; Wagner, N.; Franz, N.; Dieteren, S.; Mörs, K.; Schmidt, J.; Marzi, I.; Perl, M. Ethyl pyruvate reduces acute lung damage following trauma and hemorrhagic shock via inhibition of NF- $\mathrm{B}$ and HMGB1. Immunobiology 2018, 223, 310-318. [CrossRef] [PubMed] 
43. Shang, G.-H.; Lin, D.-J.; Xiao, W.; Jia, C.-Q.; Li, Y.; Wang, A.-H.; Dong, L. Ethyl pyruvate reduces mortality in an endotoxin-induced severe acute lung injury mouse model. Respir. Res. 2009, 10, 91. [CrossRef]

44. Luan, Z.G.; Zhang, J.; Yin, X.H.; Ma, X.C.; Guo, R.X. Ethyl pyruvate significantly inhibits tumour necrosis factor-alpha, interleukin1 beta and high mobility group box 1 releasing and attenuates sodium taurocholate-induced severe acute pancreatitis associated with acute lung injury. Clin. Exp. Immunol. 2013, 172, 417-426. [CrossRef] [PubMed]

45. Tang, D.; Kang, R.; Cheh, C.-W.; Livesey, K.M.; Liang, X.; Schapiro, N.E.; Benschop, R.; Sparvero, L.J.; Amoscato, A.; Tracey, K.J.; et al. HMGB1 release and redox regulates autophagy and apoptosis in cancer cells. Oncogene 2010, 29, 5299-5310. [CrossRef] [PubMed]

46. Alexander, E.T.; Mariner, K.; Borodyanskaya, Y.; Minton, A.; Gilmour, S.K. Polyamine-stimulation of arsenic-transformed keratinocytes. Carcinogenesis 2019, 40, 1042-1051. [CrossRef]

47. Gui, Y.; Sun, J.; You, W.; Wei, Y.; Tian, H.; Jiang, S. Glycyrrhizin suppresses epithelial-mesenchymal transition by inhibiting high-mobility group box 1 via the TGF-beta1/Smad2/3 pathway in lung epithelial cells. Peer] 2020, 8, e8514. [CrossRef] [PubMed]

48. Chen, D.; Bellussi, L.M.; Cocca, S.; Wang, J.; Passali, G.C.; Hao, X.; Chen, L.; Passali, D. Glycyrrhetinic acid suppressed hmgbl release by up-regulation of SIRT6 in Nasal inflammation. J. Biol. Regul. Homeost. Agents 2017, 31, 269-277. [PubMed]

49. Gnanasekar, M.; Shetty, A.V.; Thirugnanam, S.; Dakshinamoorthy, G.; Samykutty, A.; Zheng, G.; Chen, A.; Bosland, M.C.; Kajdacsy-Balla, A. 18 $\alpha$-glycyrrhetinic acid targets prostate cancer cells by down-regulating inflammation-related genes. Int. J. Oncol. 2011, 39, 635-640. [CrossRef]

50. Wang, K.; Shan, S.; Wang, S.; Gu, X.; Zhou, X.; Ren, T. HMGB1-containing nucleosome mediates chemotherapy-induced metastasis of human lung cancer. Biochem. Biophys. Res. Commun. 2018, 500, 758-764. [CrossRef]

51. Wu, X.; Wang, W.; Chen, Y.; Liu, X.; Wang, J.; Qin, X.; Yuan, D.; Yu, T.; Chen, G.; Mi, Y.; et al. Glycyrrhizin Suppresses the Growth of Human NSCLC Cell Line HCC827 by Downregulating HMGB1 Level. BioMed Res. Int. 2018, 2018, 6916797. [CrossRef]

52. Qiu, M.; Huang, K.; Liu, Y.; Yang, Y.; Tang, H.; Liu, X.; Wang, C.; Chen, H.; Xiong, Y.; Zhang, J.; et al. Modulation of intestinal microbiota by glycyrrhizic acid prevents high-fat diet-enhanced pre-metastatic niche formation and metastasis. Mucosal Immunol. 2019, 12, 945-957. [CrossRef] [PubMed]

53. Yao, L.; Sun, T. Glycyrrhizin administration ameliorates Streptococcus aureus-induced acute lung injury. Int. Immunopharmacol. 2019, 70, 504-511. [CrossRef] [PubMed]

54. Li, N.; Liu, X.-X.; Hong, M.; Huang, X.-Z.; Chen, H.; Xu, J.-H.; Wang, C.; Zhang, Y.-X.; Zhong, J.-X.; Nie, H.; et al. Sodium butyrate alleviates LPS-induced acute lung injury in mice via inhibiting HMGB1 release. Int. Immunopharmacol. 2018, 56, 242-248. [CrossRef]

55. Luo, Y.; Chihara, Y.; Fujimoto, K.; Sasahira, T.; Kuwada, M.; Fujiwara, R.; Fujii, K.; Ohmori, H.; Kuniyasu, H. High mobility group box 1 released from necrotic cells enhances regrowth and metastasis of cancer cells that have survived chemotherapy. Eur. J. Cancer 2013, 49, 741-751. [CrossRef] [PubMed]

56. Park, S.; Lippard, S.J. Redox State-Dependent Interaction of HMGB1 and Cisplatin-Modified DNA. Biochemistry 2011, 50, 2567-2574. [CrossRef] [PubMed]

57. Lange, S.S.; Mitchell, D.L.; Vasquez, K.M. High mobility group protein B1 enhances DNA repair and chromatin modification after DNA damage. Proc. Natl. Acad. Sci. USA 2008, 105, 10320-10325. [CrossRef] [PubMed]

58. Little, A.J.; Corbett, E.; Ortega, F.; Schatz, D.G. Cooperative recruitment of HMGB1 during V(D)J recombination through interactions with RAG1 and DNA. Nucleic Acids Res. 2013, 41, 3289-3301. [CrossRef]

59. Thwaites, D.T.; Carter, C.; Lawless, D.; Savic, S.; Boyes, J.M. A novel RAG1 mutation reveals a critical in vivo role for HMGB1/2 during V(D)J recombination. Blood 2019, 133, 820-829. [CrossRef]

60. Jamieson, E.R.; Lippard, S.J. Stopped-Flow Fluorescence Studies of HMG-Domain Protein Binding to Cisplatin-Modified DNAt. Biochemistry 2000, 39, 8426-8438. [CrossRef]

61. Jung, Y.; Lippard, S.J. Nature of Full-Length HMGB1 Binding to Cisplatin-Modified DNA. Biochemistry 2003, $42,2664-2671$. [CrossRef] [PubMed]

62. Rowell, J.P.; Simpson, K.L.; Stott, K.; Watson, M.; Thomas, J.O. HMGB1-Facilitated p53 DNA Binding Occurs via HMG-Box/p53 Transactivation Domain Interaction, Regulated by the Acidic Tail. Structure 2012, 20, 2014-2024. [CrossRef]

63. Bang, S.; Kaur, S.; Kurokawa, M. Molecular Sciences Regulation of the p53 Family Proteins by the Ubiquitin Proteasomal Pathway. Int. J. Mol. Sci. 2019, 21, 261. [CrossRef] [PubMed]

64. Štros, M.; Kučírek, M.; Sani, S.A.; Polanská, E. HMGB1-mediated DNA bending: Distinct roles in increasing p53 binding to DNA and the transactivation of p53-responsive gene promoters. Biochim. et Biophys. Acta (BBA)-Gene Regul. Mech. 2018, 1861, 200-210. [CrossRef]

65. Yang, H.; Wang, H.; Chavan, S.S.; Andersson, U. High Mobility Group Box Protein 1 (HMGB1): The Prototypical Endogenous Danger Molecule. Mol. Med. 2015, 21, S6-S12. [CrossRef] [PubMed]

66. Chen, G.; Li, J.; Ochani, M.; Rendon-Mitchell, B.; Qiang, X.; Susarla, S.; Ulloa, L.; Yang, H.; Fan, S.; Goyert, S.M.; et al. Bacterial endotoxin stimulates macrophages to release HMGB1 partly through CD14- and TNF-dependent mechanisms. J. Leukoc. Biol. 2004, 76, 994-1001. [CrossRef]

67. Yang, Z.; Li, L.; Chen, L.; Yuan, W.; Dong, L.; Zhang, Y.; Wu, H.; Wang, C. PARP-1 Mediates LPS-Induced HMGB1 Release by Macrophages through Regulation of HMGB1 Acetylation. J. Immunol. 2014, 193, 6114-6123. [CrossRef] 
68. Bonaldi, T.; Talamo, F.; Scaffidi, P.; Ferrera, D.; Porto, A.; Bachi, A.; Rubartelli, A.; Agresti, A.; Bianchi, M.E. Monocytic cells hyperacetylate chromatin protein HMGB1 to redirect it towards secretion. EMBO J. 2003, 22, 5551-5560. [CrossRef]

69. Volchuk, A.; Ye, A.; Chi, L.; Steinberg, B.E.; Goldenberg, N.M. Indirect regulation of HMGB1 release by gasdermin D. Nat. Commun. 2020, 11, 1-11. [CrossRef]

70. Ito, I.; Fukazawa, J.; Yoshida, M. Post-translational Methylation of High Mobility Group Box 1 (HMGB1) Causes Its Cytoplasmic Localization in Neutrophils. J. Biol. Chem. 2007, 282, 16336-16344. [CrossRef]

71. Richard, S.A.; Jiang, Y.; Xiang, L.H.; Zhou, S.; Wang, J.; Su, Z.; Xu, H. Post-translational modifications of high mobility group box 1 and cancer. Am. J. Transl. Res. 2017, 9, 5181-5196.

72. Youn, J.H.; Shin, J.-S. Nucleocytoplasmic Shuttling of HMGB1 Is Regulated by Phosphorylation That Redirects It toward Secretion. J. Immunol. 2006, 177, 7889-7897. [CrossRef] [PubMed]

73. Lu, B.; Antoine, D.J.; Kwan, K.; Lundbäck, P.; Wähämaa, H.; Schierbeck, H.; Robinson, M.; Van Zoelen, M.A.D.; Yang, H.; Li, J.; et al. JAK/STAT1 signaling promotes HMGB1 hyperacetylation and nuclear translocation. Proc. Natl. Acad. Sci. USA 2014, 111, 3068-3073. [CrossRef]

74. Kim, Y.H.; Kwak, M.S.; Park, J.B.; Lee, S.A.; Choi, J.E.; Cho, H.S.; Shin, J.S. N-linked glycosylation plays a crucial role in the secretion of HMGB1. J. Cell Sci. 2016, 129, 29-38. [CrossRef] [PubMed]

75. Davis, K.; Banerjee, S.; Friggeri, A.; Bell, C.; Abraham, E.; Zerfaoui, M. Poly(ADP-Ribosyl)ation of High Mobility Group Box 1 (HMGB1) Protein Enhances Inhibition of Efferocytosis. Mol. Med. 2011, 18, 359-369. [CrossRef]

76. Tang, D.; Kang, R.; Zeh III, H.J.; Lotze, M.T. High-mobility group box 1, oxidative stress, and disease. Antioxid. Redox Signal. 2011, 14, 1315-1335. [CrossRef] [PubMed]

77. Venereau, E.; Casalgrandi, M.; Schiraldi, M.; Antoine, D.J.; Cattaneo, A.; De Marchis, F.; Liu, J.; Antonelli, A.; Preti, A.; Raeli, L.; et al. Mutually exclusive redox forms of HMGB1 promote cell recruitment or proinflammatory cytokine release. J. Exp. Med. 2012, 209, 1519-1528. [CrossRef]

78. Sims, G.P.; Rowe, D.C.; Rietdijk, S.T.; Herbst, R.; Coyle, A.J. HMGB1 and RAGE in Inflammation and Cancer. Annu. Rev. Immunol. 2010, 28, 367-388. [CrossRef]

79. Yu, M.; Wang, H.; Ding, A.; Golenbock, D.T.; Latz, E.; Czura, C.J.; Fenton, M.J.; Tracey, K.J.; Yang, H. HMGB1 signals through toll-like receptor (TLR) 4 and TLR2. Shock 2006, 26, 174-179. [CrossRef] [PubMed]

80. Liu, A.; Jin, H.; Dirsch, O.; Deng, M.; Huang, H.; Bröcker-Preuss, M.; Dahmen, U. Release of Danger Signals during Ischemic Storage of the Liver: A Potential Marker of Organ Damage? Mediat. Inflamm. 2010, 2010, 436145. [CrossRef]

81. Zhang, Q.Y.; Wu, L.Q.; Zhang, T.; Han, Y.F.; Lin, X. Autophagy-mediated HMGB1 release promotes gastric cancer cell survival via RAGE activation of extracellular signal-regulated kinases 1/2. Oncol. Rep. 2015, 33, 1630-1638. [CrossRef]

82. Zheng, L.; Zhu, Q.; Xu, C.; Li, M.; Li, H.; Yi, P.; Xu, F.; Cao, L.; Chen, J. Glycyrrhizin mitigates radiation-induced acute lung injury by inhibiting the HMGB1/TLR4 signalling pathway. J. Cell. Mol. Med. 2020, 24, 214-226. [CrossRef]

83. Tan, J.; Zhao, F.; Deng, S.; Zhu, H.; Gong, Y.; Wang, W. Glycyrrhizin affects monocyte migration and apoptosis by blocking HMGB1 signaling. Mol. Med. Rep. 2018, 17, 5970-5975. [CrossRef]

84. Curtin, J.F.; Liu, N.; Candolfi, M.; Xiong, W.; Assi, H.; Yagiz, K.; Edwards, M.R.; Michelsen, K.S.; Kroeger, K.M.; Liu, C.; et al. HMGB1 Mediates Endogenous TLR2 Activation and Brain Tumor Regression. PLoS Med. 2009, 6, e1000010. [CrossRef]

85. Chai, Y.; Xiao, J.; Zhang, S.; Du, Y.; Luo, Z.; Zhou, X.; Huang, K. High-mobility group protein B1 silencing promotes susceptibility of retinoblastoma cells to chemotherapeutic drugs through downregulating nuclear factor-kB. Int. J. Gynecol. Cancer 2017, 18, 1651-1658.

86. Lu, B.; Nakamura, T.; Inouye, K.; Li, J.; Tang, Y.; Lundbäck, P.; Valdes-Ferrer, S.I.; Olofsson, P.S.; Kalb, T.; Roth, J.; et al. Novel role of PKR in inflammasome activation and HMGB1 release. Nat. Cell Biol. 2012, 488, 670-674. [CrossRef] [PubMed]

87. Thorburn, J.; Horita, H.; Redzic, J.; Hansen, K.; Frankel, A.E. Autophagy regulates selective HMGB1 release in tumor cells that are destined to die. Cell Death Differ. 2008, 16, 175-183. [CrossRef]

88. Booth, L.; Roberts, J.L.; Poklepovic, A.; Dent, P. [pemetrexed + sildenafil], via autophagy-dependent HDAC downregulation, enhances the immunotherapy response of NSCLC cells. Cancer Biol. Ther. 2017, 18, 705-714. [CrossRef] [PubMed]

89. Wang, W.; Chapman, N.M.; Zhang, B.; Li, M.; Fan, M.; Laribee, R.N.; Zaidi, M.R.; Pfeffer, L.M.; Chi, H.; Wu, Z.H. Upregulation of PD-L1 via HMGB1-activated IRF3 and NF-kB contributes to UV radiation-induced immune suppression. Cancer Res. 2019, 79, 2909-2922. [CrossRef] [PubMed]

90. Hubert, P.; Roncarati, P.; Demoulin, S.; Pilard, C.; Ancion, M.; Reynders, C.; Lerho, T.; Bruyere, D.; Lebeau, A.; Radermecker, C.; et al. Extracellular HMGB1 blockade inhibits tumor growth through profoundly remodeling immune microenvironment and enhances checkpoint inhibitor-based immunotherapy. J. Immunother. Cancer 2021, 9, e001966. [CrossRef] 